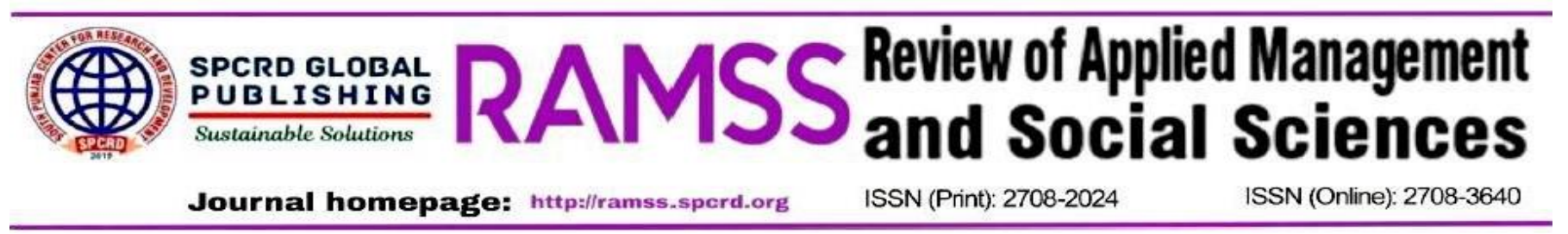

\title{
How Subjective Career Success of Public Sector Universities' Teachers Is Affected by Protean Career Orientation?
}

\author{
${ }^{a}$ Muhammad Farooq Rehan, ${ }^{b}$ Quaisar Ijaz Khan, ${ }^{c}$ Raheel Mumtaz \\ ${ }^{a}$ Assistant Professor, Government College University Faisalabad, , Pakistan \\ Email: farooq.rehan@gcuf.edu.pk \\ ${ }^{\mathrm{b}}$ Assistant Professor, Government College University Faisalabad, Pakistan \\ Email: qaisar@gcuf.edu.pk \\ ${ }^{\mathrm{c}}$ Assistant Professor, Government College University Faisalabad, Pakistan \\ Email: raheelmumtaz@gcuf.edu.pk
}

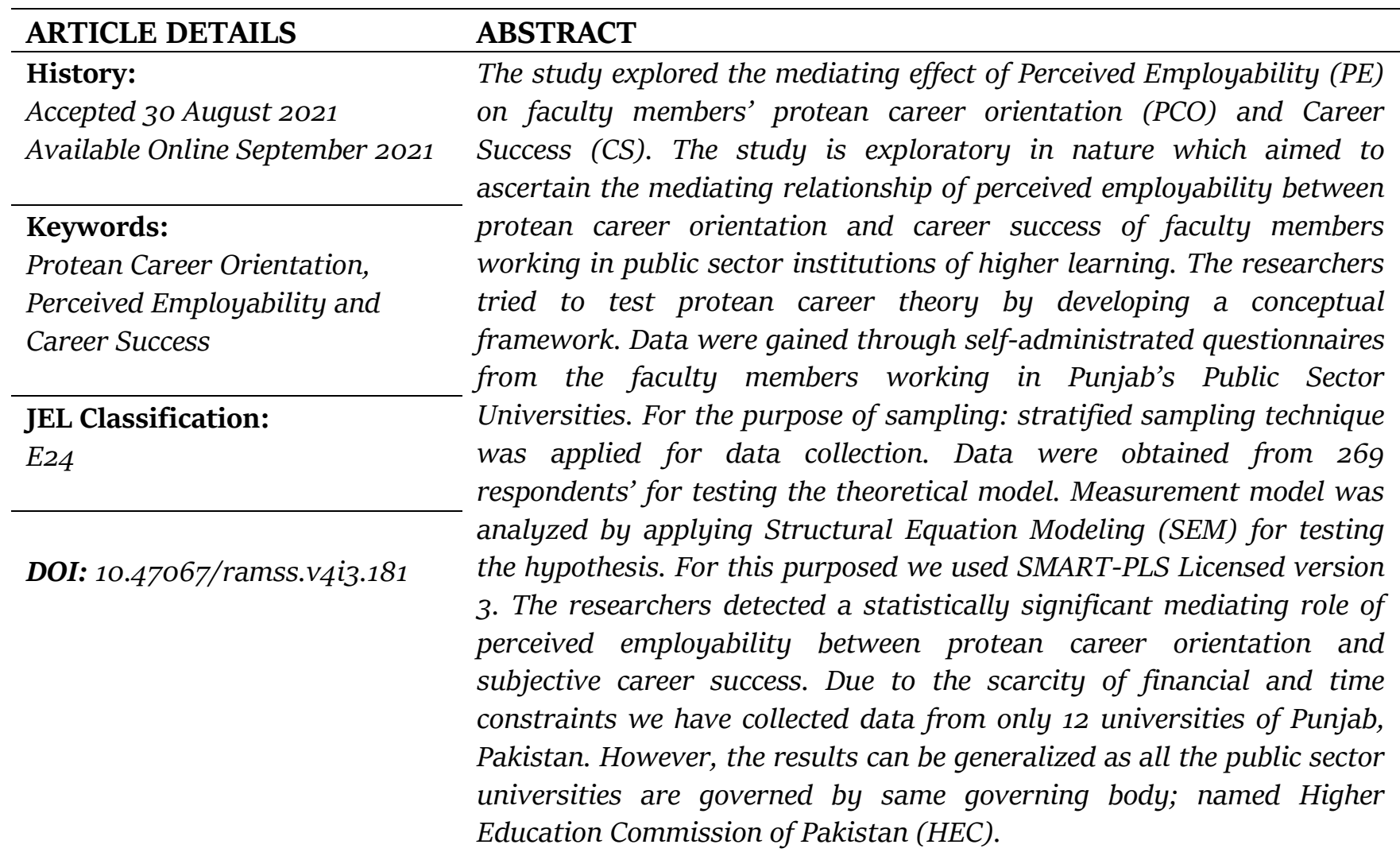

(C) 2021 The authors. Published by SPCRD Global Publishing. This is an open-access article under the Creative Commons Attribution-

NonCommercial 4.0

Corresponding author's email address: raheelmumtaz@gcuf.edu.pk

\section{Introduction}

In the era of globalization, the business world is rapidly changing. Organizational employees are more focusing on their career advancement therefore; they are shaping their career in way to 
cope with rapidly changing business word. Hall (1976) introduced the term Protean Career (PC), which is actually originated from Greek's god of sea, Proteus, accordingly to their beliefs their god can change his shape in order to avoid enemies. Thus PC is all about evolution of career (Hall, Lee, Kossek, \& Heras, 2012). In today world, where career landscape is changing, workers are adopting PC orientation. Briscoe, Hall, and DeMuth (2006) suggested that protean careerist incorporate the changes in their career according their new priorities. It is pertinent from the literature that PC orientation has an impact on career success of the workers (Alani, Khan, \& Manuel, 2018). Human resource expert has given importance to subjective career success phenomenon after the appearance of an adjustable work attitude in the literature (Herrmann, Hirschi, \& Baruch, 2015). Moreover, the researcher showed their interest in other HR concepts such as employability perceptions and employees' affective commitment because employers are showing great concerns in these phenomenon (Muslim, Ismail, Rasid, \& Selemani, 2014).

In today's changing word, just perception of being employable causes the job satisfaction as behaviors, attitudes, and actions are impacted by these perceptions. In recent times, perceived employability is receiving significant attention because of ever changing environment. As per human capital theory, employee make investments in learning valuable skills to be employable in the job market (Herrmann et al., 2015; Ng, Gossett, Chinyoka, \& Obasi, 2016; Zafar \& Farooq, 2017). Keeping in view the change job market, employees are becoming more adaptable to ever changing workplace. Moreover, employees are getting emotionally attached with their organization as consequence of high perception of being employable (Saari \& Judge, 2004). Lumley et al. (2011) emphasize that the employee who have high affective commitment with their organization are more likely to have better career success (Quaisar, Shukor, \& Soffian, 2016b).

There is consensus that teachers feel very happy with their career because they think that with their career making their students are making their career (Judge, Cable, Boudreau, and Bretz, 1994). However, this can only be achieved by the happy faculty members, on the other hand unsatisfied university faculty do not perform to the best of their abilities and are more likely to have turnover intentions (Quaisar, Shukor, \& Soffian, 2016a). Faculty turnover is having negative impact on the organization, because new placement needs lots of money (Zafar \& Farooq, 2017). Higher education teaching in Pakistan is becoming more professional and consumer driven especially in public sector (Saher, Bibi, Farmanullah, \& Abbas, 2014). Furthermore, the number of higher educational institutions (HEI) are increasing highly.

Since the topic of career success and job satisfaction are gaining significance especially in private as well as in public sector of Pakistan, the factors causing impact on career success in changing environment need to be considered. Therefore, the present research focuses to investigate the impact of PC on subjective career success. In today's changing word, just perception of being employee causes the job satisfaction as behaviors, attitudes, and actions are impacted by these perceptions (Quddus et al., 2020). Moreover, the research on other career related notion such as perceived employability, employee commitment in relation to PC orientation and subjective career success are novel in the context of developing countries like Pakistan. These phenomena are well research in developed countries. However, in the context of developing countries like Pakistan, the research on subjective career success topic in relation to protean career orientation is needed. Therefore, the present study is aimed to examine following research question; 
1. How subjective career success of faculty members working in public sector universities of Pakistan is influenced by protean career orientation?

2. How perceived employability of faculty members working in public sector universities of Pakistan is influenced by protean career orientation?

3. How career success of faculty members working in public sector universities of Pakistan is influenced by perceived employability?

4. How perceived employability mediates the relationship of PCO and subjective career success of faculty members working in public sector universities of Pakistan?

To answer these question, the research study used primary data collected from the faculty members working in public sector universities of Pakistan. The instrument i.e., Questionnaire for data collection was adopted. A total of 400 questionnaires were distributed and 269 responses were found to be suitable for use in further data analysis. PLS-SEM technique was used for the analysis of data collected from the faculty members faculty members working in public sector universities of Pakistan. The present study has very valuable theoretical and practical implications. These implications are very beneficial for academic researchers as well as for policy makers.

\section{Literature Review}

\subsection{Subjective Career Success}

According to Seibert, et al. (1999) subjective career success is about achievements made during the progress in career, and getting what is anticipated to be achieved by the career aspirant. Previous studies have operationalized it as job satisfaction as well as career satisfaction (Mohd, Ismail, \& Garavan, 2011; Tabiu \& Nura, 2013; Tan \& Khulida, 2011). However, job satisfaction is workers feeling of being either satisfied or dissatisfied about their job. on the other hand career satisfaction is about employee's feeling of being satisfied or dissatisfied about his career path (Bashir, Bashir, Rana, Lambert, \& Vernallis, 2021; Gibari, Perez-Esparrells, Gomez, \& Ruiz, 2021; Quaisar, Shukor, \& Soffian, 2015). Although both concepts are related with work satisfaction nevertheless these are different from each other (Shen, Demel, Unite, Briscoe, \& Hall, 2014). Thus, the current study operationalized subjective career success as career satisfaction of faculty members working in public sector universities of Pakistan. However, career success has two dimensions intrinsic and extrinsic. The current study has examined only intrinsic career success, as extrinsic portion is measured by someone else, other than faculty member himself/herself.

\subsection{Protean career orientation}

Hall (1976) introduced the term Protean Career which is actually originated from Greek's god of sea, Proteus, accordingly to their beliefs, their god can change his shape in order to avoid enemies. Quaisar et al. (2016), refers protean career as future oriented, proactive, and adaptive to change career. The term Protean career orientation is defined by Briscoe and Hall (2006) as employee's perception about protean career. Researchers in past refers that an employee who has protean career orientation is more flexible, versatile, and adaptive to change in this dynamic job market where employees are facing rescission, downsizing, merger \& acquisition situations, and even harassments. Such complex environmental changes have affected protean career aspirants. Because of ever change environmental condition, there is dire need of investigating the impact of protean career orientation of different behaviors (Quaisar, Khulida, \& Tan, 2014).

\subsection{Perceived Employability}

De Cuyper et al. (2011) defined perceived employability as employee belief about the chances 
of getting better job opportunities. In simple it is perception of being employable or chances of getting better and new job (Rothaermel \& Thursby, 2005). According to Rothwell and Arnold (2007) this concept evolve over the time, employability was considered as one's ability to be employed in job market (Griffith, 2004). However, now it become overall attitude of employees towards employment. Perceived employability, therefore, is an overall reflection of the employee attitude in the job market; the more an individual consider himself employable, the less he will feel the strain on the and more will be his career satisfaction.

\subsection{Hypotheses Development}

After doing extensive literature review, the study formed following relationship between the variables under discussion.

\subsubsection{Protean Career Orientation and Subjective Career Success}

De Vos and De Soens (2008) describe protean career orientation as a personal feeling that helps in managing individual's career. The individual with these feelings are very proactive in managing their career path and protean careerist are dependent upon their own values rather than the environment (Alfes, Shantz, Truss, \& Soane, 2013). In order to achieve their career goals, protean careerist make right choice (Bruursema, Kessler, \& Spector, 2011). Individual who behave more proactively in managing their career are more successful in their career and their proactive behaviors found to have very good association with career success (Seibert \& Kraimer, 2001). Fuller and Marler (2009) also found that protean career orientation and subjective career success are significantly associated with each other because protean careerists put more emphasis on achieving personal career goals. Therefore, the current study hypothesized that;

H1: The subjective career success of the individual is positively influenced by the protean career orientation.

\subsubsection{Protean Career Orientation and Perceived Employability}

The changes are taking place in the economy and career processes are getting transformed too. Few years ago, employee considered themselves to be employed by any organization for the life time and it was all steady upward career path and employee loyalty with his organization traditionally (Zhang, Jiang, Liu, \& Liu, 2020). However, in dynamic environment, no-one can guarantee for life time employment in the same organization. Therefore, individual need to manage their career in a way that they can remain employable in the job market. In the changing job world, if a person is adaptable and flexible then his tendency of being employable will be high in the job market. De Vos and Soens (2008) were of the view that individual's protean career orientation helps in attaining the perception of being employable by managing their competencies because protean careerist vales more on achieving personal career goals. And they are quick in adapting the environmental changes in the job market (Hall, 2002). Past literature show that individual with protean career orientation are more likely to develop skill and career related competencies so that they can remain employable in the market (Yudianto, Mulyani, Fahmi, \& Winarningsih, 2021). Moreover, the employee who develop the career competencies as protean careerist do, are more likely to remain employable and Water et al. (2014) found the positive relationship between protean career orientations and perceived employability. Therefore, the current study hypothesized that; H2: The perceived employability of the individual is positively associated with protean career orientation. 


\subsubsection{Perceived Employability and Subjective Career Success}

In the contemporary world, employees are required to be more career oriented then the employer oriented and therefore it is becoming very significant that employee learn new competencies according to the need of the job market to remain employable. These changes shift the attention of employees to their career path rather upward moving in the same organization (Hall, 2004). Therefore, by enhancing the competencies the employees enhance their perception of being employable. Moreover, there are numerous empirical evidences that support the notion that career success or outcome are influenced by the perceived employability (Alshammari, 2019; Baltaru, 2019; Blasco, Brusca, \& Labrador, 2019; Lee \& Kim, 2019). Therefore, it is assumed and hypothesized that; H3: The subjective career success of the individual is positively associated with perceived employability of the individuals.

\subsubsection{Perceived Employability, Protean Career Orientation and Subjective Career Success}

The traditional concept of being employee for life time has become obsolete and now employees are more career oriented (Alani et al., 2018). There one thing that is constant which is change. In this contemporary changing world employee wanted to remain employable, therefore, employee is more adaptive and flexible in learning modern skills. So that they can grow in their career. Therefore, individual with protean career orientation as being more self-directed, more career oriented, adaptive to change, and flexible are have better perceived employability and in turn it has influence on their career satisfaction. It is thus hypothesized that;

H4: The relationship between protean career orientation and subjective career success is mediated by perceived employability of the employee.

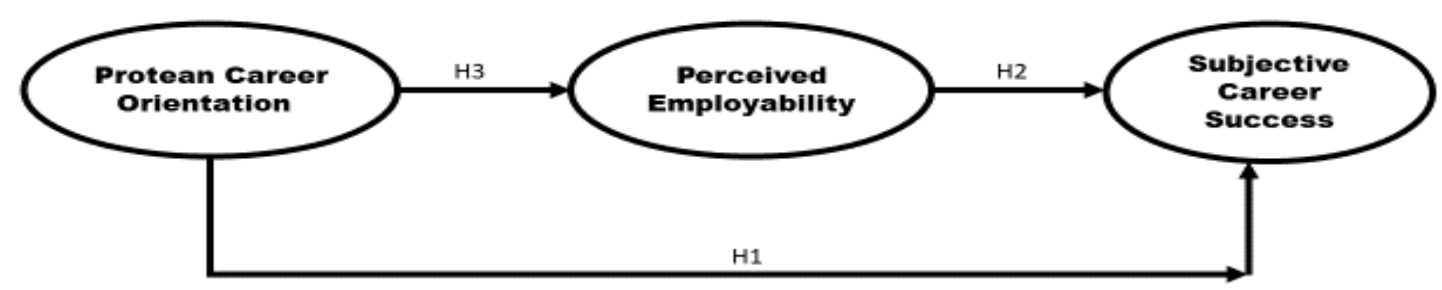

\section{Methodology}

The present study used positivism paradigm because it is most suitable paradigm for business and management studies (Rabovsky, 2012). The positivists' approach stressed upon the use quantitative research methods in order to determine the causation relation between variables. Furthermore, the current study is cross-sectional study because of budget and time constraints. The current study is inferential study with individual as unit of analysis.

The population of this study are the teaching faculty employed by public sector HEI of Pakistan. The study employed proportionate stratified random sampling technique in order to get more representation. We distributed a total of 400 questionnaires by doing online as well as physical survey. After receiving the responses and initial analysis of filled questionnaires, it was found that a 
total of 269 responses were consider fit for further analysis..

\subsection{Measures}

As the data for this study was collected by using questionnaire and the items of the concerned variables were adopted from the previous literature. The dependent variable for the current study is Subjective Career Success. Item of the subjective career success were adopted from Greenhaus et al. (1990). As per Greenhause et al. (1990) subjective career satisfaction is feelings of satisfaction about career. The independent variable of the present study is Protean Career Orientation. It refers to the degree of individual's proactivity and flexibility during their career (Baeriswyl, Krause, \& Schwaninger, 2016). The 6 items of protean career orientation were adopted from the study by Junaid (2017). The mediating variable of this study is Perceived Employability. It refers to perception or beliefs of finding better or new jobs (De Cuyper et al. 2011). De Cuyper et al used 4 tem scale to measure perceived employability and the current study adopted the same for use. Moreover, the instrument used five-point Liker scale for measuring all these constructs. The study seeks the respondent to rate the items from 1 (lowest) to 5 (highest).

\section{Results and Analysis}

This section deals with the statical findings whereas, Figure 1 represents the basic algorithm for the statistical model of the study as follow:

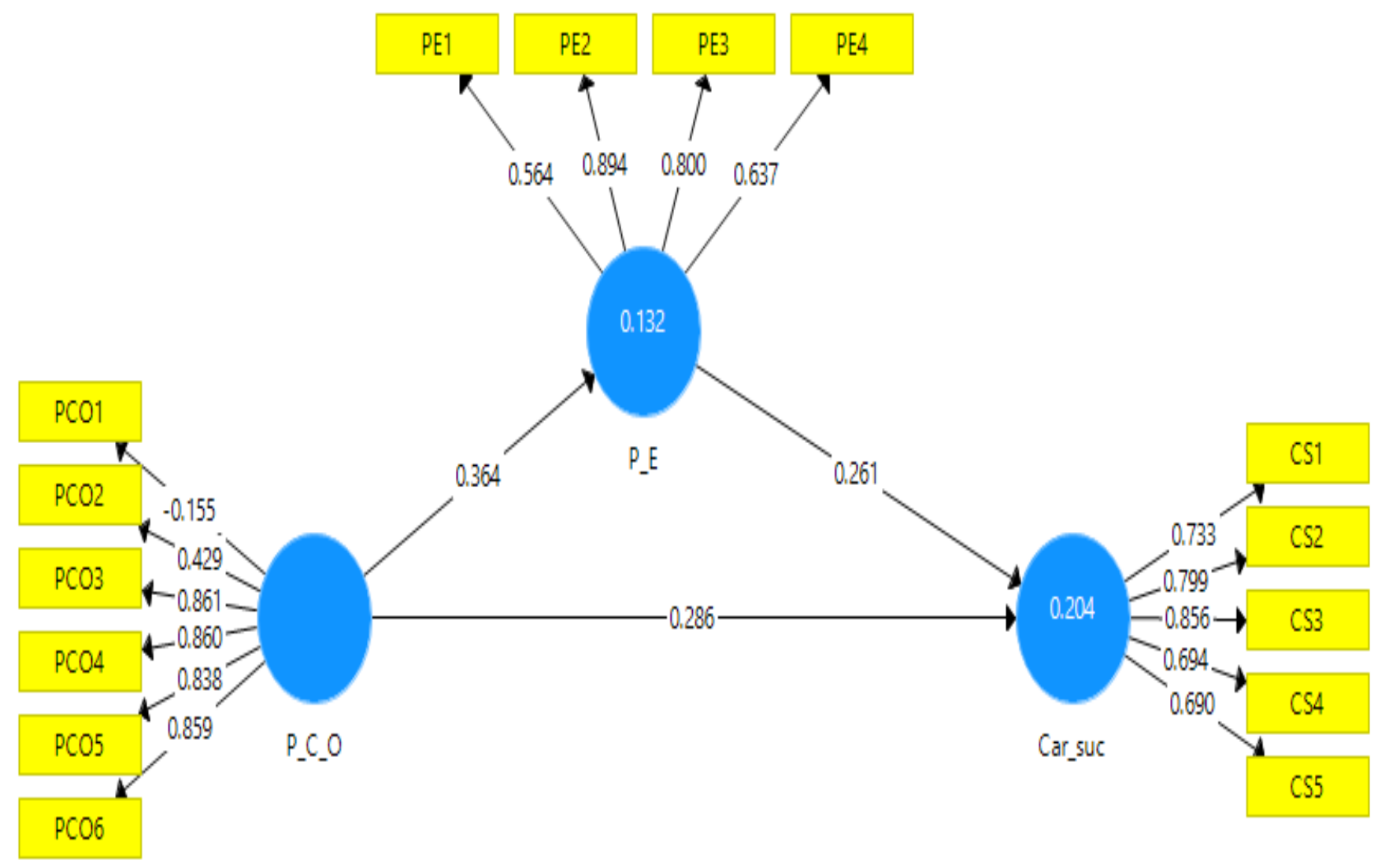

Figure: $\quad 1.1 \quad$ Presents the Basic Algorithm for the model 
Review of Applied Management and Social Sciences (RAMSS) Vol. 4, (3) 2021, $761-772$

For further clarification regarding validity and reliability of the model and selection criteria of this construct is presented here in different tables as follow:

Table: 1.1 Represents Factor Loading for the construct as below:

\begin{tabular}{|l|l|l|l|}
\hline & Car_suc & P_C_O & P_E \\
\hline CS1 & 0.733 & & \\
\hline CS2 & 0.799 & & \\
\hline CS3 & 0.856 & & \\
\hline CS4 & 0.694 & & \\
\hline CS5 & 0.690 & & \\
\hline PCO1 & & -0.155 & \\
\hline PCO2 & & 0.429 & \\
\hline PCO3 & & 0.861 & \\
\hline PCO4 & & 0.860 & \\
\hline PCO5 & & 0.838 & \\
\hline PCO6 & & 0.859 & 0.564 \\
\hline PE1 & & & 0.894 \\
\hline PE2 & & & 0.800 \\
\hline PE3 & & & 0.637 \\
\hline PE4 & & & \\
\hline
\end{tabular}

Table: 1.2 Construct Reliability and Validity

\begin{tabular}{|l|l|l|l|l|}
\hline & Cronbach's Alpha & rho_A & Composite Reliability & Average Variance Extracted (AVE) \\
\hline Car_suc & 0.816 & 0.832 & 0.870 & 0.573 \\
\hline P_C_O & 0.758 & 0.891 & 0.826 & 0.522 \\
\hline P_E & 0.702 & 0.723 & 0.820 & 0.540 \\
\hline
\end{tabular}

Table: 1.3 Discriminant Validity (Fornell-Larcker Criterion)

\begin{tabular}{|l|l|l|l|}
\hline & Car_suc & P_C_O & P_E \\
\hline Car_suc & 0.757 & & \\
\hline P_C_O & 0.381 & 0.722 & \\
\hline P_E & 0.365 & 0.364 & 0.735 \\
\hline
\end{tabular}

The next table is presented here to demonstrate Variance Inflation Factor (VIF). VIF is a measure of multicollinearity. This ratio is calculated for all exogenous variable of the study. A great VIF values indicate the associated independent variable is extremely collinear with the other variables of the construct. Table 1.4 is provided as follow: 
Review of Applied Management and Social Sciences (RAMSS) Vol. 4, (3) 2021, $761-772$

Table: 1.4 Collinearity Statistics (VIF)

\begin{tabular}{|l|l|}
\hline & VIF \\
\hline CS1 & 3.841 \\
\hline CS2 & 5.283 \\
\hline CS3 & 2.695 \\
\hline CS4 & 1.840 \\
\hline CS5 & 1.924 \\
\hline PCO1 & 1.560 \\
\hline PCO2 & 2.356 \\
\hline PCO3 & 2.924 \\
\hline PCO4 & 3.979 \\
\hline PCO5 & 3.750 \\
\hline PCO6 & 2.203 \\
\hline PE1 & 1.345 \\
\hline PE2 & 3.099 \\
\hline PE3 & 2.398 \\
\hline PE4 & 1.195 \\
\hline
\end{tabular}

Table: 1.5 Model Fit Criteria

\begin{tabular}{|l|l|l|}
\hline & Saturated Model & Estimated Model \\
\hline SRMR & 0.144 & 0.144 \\
\hline d_ULS & 2.498 & 2.498 \\
\hline d_G & 2.200 & 2.200 \\
\hline Chi-Square & 2160.632 & 2160.632 \\
\hline NFI & 0.383 & 0.383 \\
\hline
\end{tabular}

Table: 1.6 Model Selection Criteria

\begin{tabular}{|c|c|c|c|c|c|c|}
\hline & 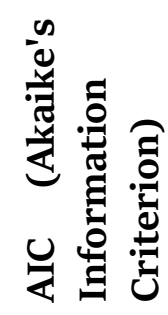 & 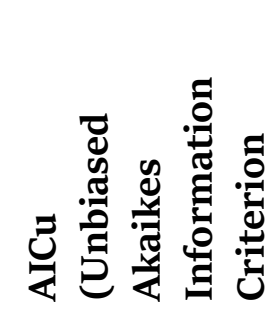 & 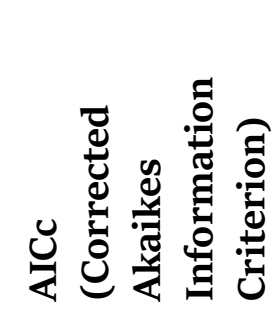 & ن & 胥 & 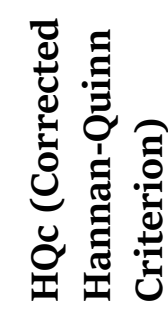 \\
\hline Car_suc & -56.588 & -53.571 & $215 \cdot 563$ & $-45 \cdot 792$ & -52.253 & -52.058 \\
\hline P_E & $-35 \cdot 307$ & -33.299 & 236.784 & -28.110 & -32.417 & -32.313 \\
\hline
\end{tabular}

After assessing the model statically fit for the analysis the research study represents the following figure 1.2 that represents the T-statistics for the hypothesis testing the figure is represented as below: 


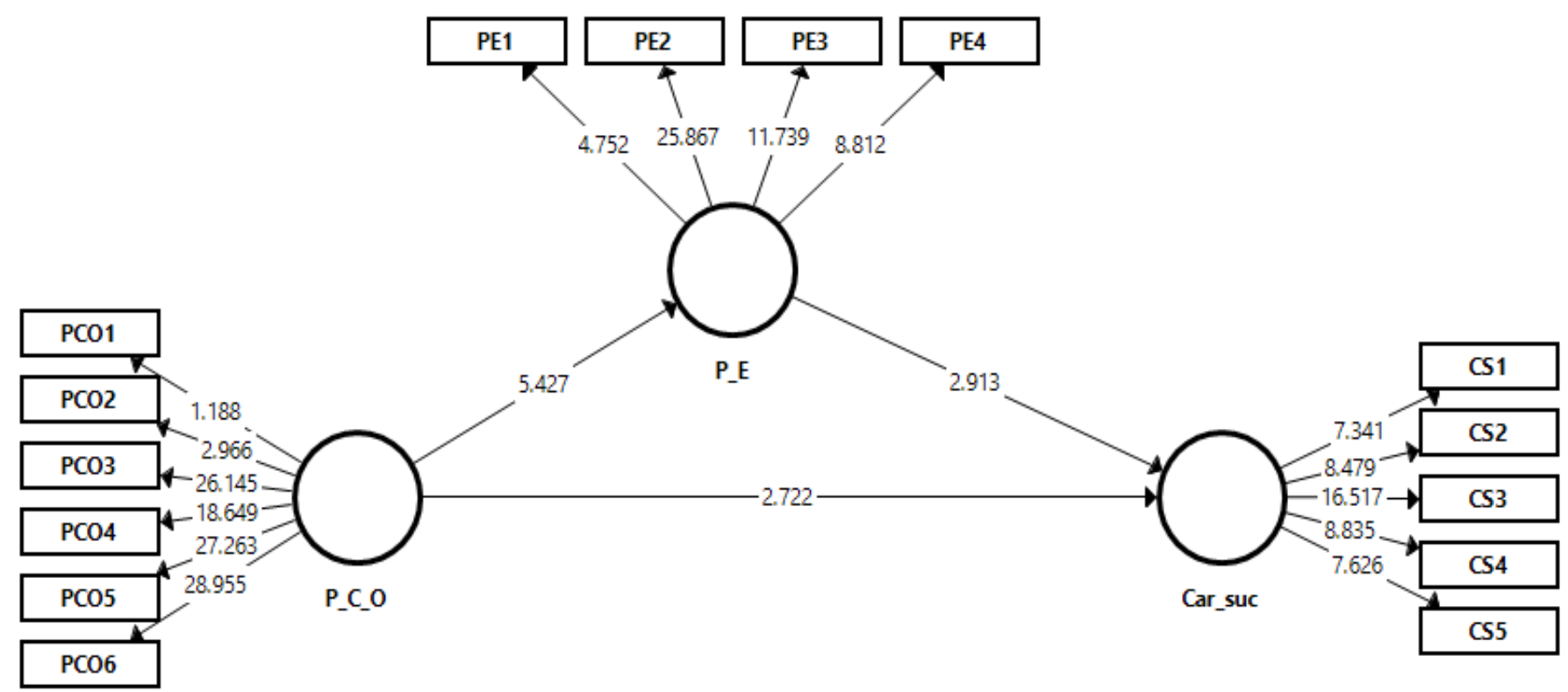

Figure: $\quad \mathbf{1 . 2}$ Represents The T-Statistics for Hypothesis Testing

Table: 1.7 Path Coefficient

\begin{tabular}{|c|c|c|c|c|c|}
\hline & 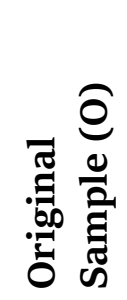 & 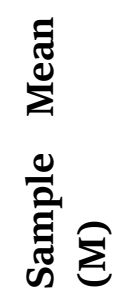 & 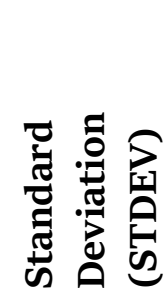 & 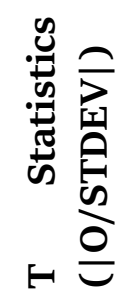 & 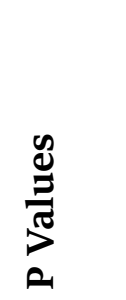 \\
\hline P_C_O -> Car_suc & 0.286 & 0.289 & 0.105 & 2.722 & 0.007 \\
\hline P_C_O -> P_E & 0.364 & 0.371 & 0.067 & 5.427 & 0.000 \\
\hline P_E -> Car_suc & 0.261 & 0.275 & 0.090 & 2.913 & 0.004 \\
\hline
\end{tabular}

Table: 1.8 Represents Total Indirect Effect

\begin{tabular}{|c|c|c|c|c|c|}
\hline & 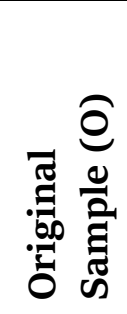 & 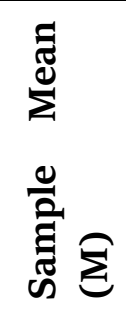 & 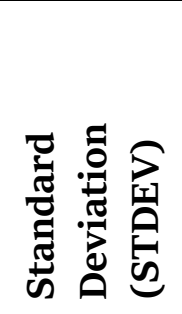 & 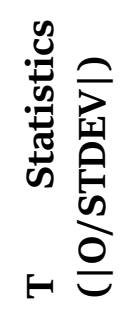 & $\begin{array}{l}\frac{y}{3} \\
\frac{\pi}{10} \\
0\end{array}$ \\
\hline P_C_O -> Car_suc & 0.095 & 0.101 & 0.035 & 2.679 & 0.008 \\
\hline \multicolumn{6}{|l|}{ P_C_O -> P_E } \\
\hline P_E -> Car_suc & & & & & \\
\hline
\end{tabular}


Table: 1.9 Represents Specific indirect Effect

\begin{tabular}{|c|c|c|c|c|c|}
\hline & ฮี & 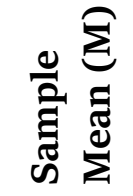 & 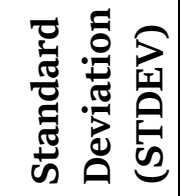 & 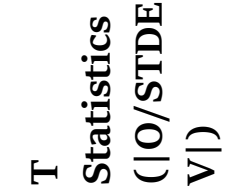 & 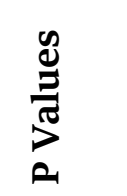 \\
\hline P_C_O -> P_E -> Car_suc & 0.095 & 0.101 & 0.035 & 2.679 & 0.008 \\
\hline
\end{tabular}

Table: 1.10 Total effects is represented

\begin{tabular}{|c|c|c|c|c|c|}
\hline & 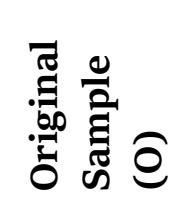 & 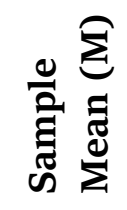 & 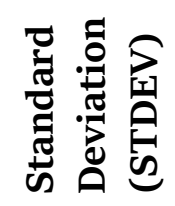 & 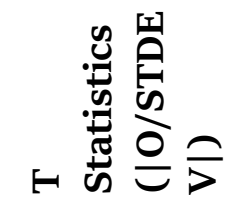 & 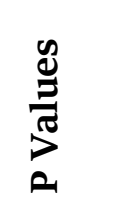 \\
\hline P_C_O -> Car_suc & 0.381 & 0.390 & 0.088 & $4 \cdot 322$ & 0.000 \\
\hline P_C_O -> P_E & 0.364 & 0.371 & 0.067 & 5.427 & 0.000 \\
\hline P_E -> Car_suc & 0.261 & 0.275 & 0.090 & 2.913 & 0.004 \\
\hline
\end{tabular}

\section{Discussion and Future Recommendations:}

The study tested four hypothesis; it has been found that the PCO and PE are positively significant with career success of the faculty members working in public sector universities of Pakistan. Furthermore, the current study has found the mediating relationship of perceived employability between protean career orientation and career success of faculty members working in public sector universities of Pakistan. Due to the scarcity of time and financial constraints the study is limited to 12 universities of Punjab, Pakistan. Although, the results can be generalized. Future researchers are recommended to conduct qualitative research for the construct in the context of Pakistan.

\section{References}

Alani, F. S., Khan, M. F. R., \& Manuel, D. F. (2018). University performance evaluation and strategic mapping using balanced scorecard (BSC): Case study - Sohar University, Oman. International Journal of Educational Management, 32(4), 689-70o. https://doi.org/10.1108/IJEM-05-20170107

Alfes, K., Shantz, A. D., Truss, C., \& Soane, E. C. (2013). The link between perceived human resource management practices, engagement and employee behaviour: a moderated mediation model. International Journal of Human Resource Management, 24(2), 330-351. https://doi.org/10.1080/09585192.2012.679950

Alshammari, E. (2019). Stress profile and university performance of pharmacy students. International Journal of Research in Pharmaceutical Sciences, 10(4), 2647-2653. https://doi.org/10.26452/ijrps.v10i4.1522

Baeriswyl, S., Krause, A., \& Schwaninger, A. (2016). Emotional Exhaustion and Job Satisfaction in Airport Security Officers - Work-Family Conflict as Mediator in the Job Demands-Resources Model. Frontiers in Psychology, 7, 663. https://doi.org/10.3389/fpsyg.2016.00663

Baltaru, R. D. (2019). Do non-academic professionals enhance universities' performance? Reputation vs. organisation. Studies in Higher Education, 44(7), 1183-1196. 
https://doi.org/10.1080/03075079.2017.1421156

Bashir, A., Bashir, S., Rana, K., Lambert, P., \& Vernallis, A. (2021). Post-COVID-19 Adaptations; the Shifts Towards Online Learning, Hybrid Course Delivery and the Implications for Biosciences Courses in the Higher Education Setting. Frontiers in Education, 6, 310. https://doi.org/10.3389/FEDUC.2021.711619/BIBTEX

Blasco, N., Brusca, I., \& Labrador, M. (2019). Assessing sustainability and its performance implications: An empirical analysis in Spanish public universities. Sustainability (Switzerland), 11(19). https://doi.org/10.3390/su11195302

Bruursema, K., Kessler, S. R., \& Spector, P. E. (2011). Bored employees misbehaving: The relationship between boredom and counterproductive work behaviour. Work \& Stress, 25(2), 93-107. https://doi.org/10.1080/02678373.2011.596670

Gibari, S. El, Perez-Esparrells, C., Gomez, T., \& Ruiz, F. (2021). Analyzing the impact of spanish university funding policies on the evolution of their performance: a multi-criteria approach. Mathematics, 9(14), 1-34. https://doi.org/10.339o/math9141626

Griffith, J. (2004). Relation of principal transformational leadership to school staff job satisfaction, staff turnover, and school performance. Journal of Educational Administration, 42(3), 333356. https://doi.org/10.1108/09578230410534667

Hall, D. T., Lee, M. D., Kossek, E. E., \& Heras, M. Las. (2012). Pursuing Career Success while Sustaining Personal and Family Well-Being: A Study of Reduced-Load Professionals over Time. Journal of Social Issues, 68(4), 742-766. https://doi.org/10.1111/j.15404560.2012.01774.x

Herrmann, A., Hirschi, A., \& Baruch, Y. (2015). The protean career orientation as predictor of career outcomes: Evaluation of incremental validity and mediation effects. Journal of Vocational Behavior, 88, 205-214. https://doi.org/10.1016/j.jvb.2015.03.008

Lee, Y. H., \& Kim, H. K. (2019). Financial support and university performance in Korean universities: A panel data approach. Sustainability (Switzerland), 11(20), 1-18. https://doi.org/10.3390/su11205871

Mohd, R., Ismail, M., \& Garavan, T. N. (2011). Predicting Malaysian managers objective and subjective career success. The International Journal of Human Resource Management, 22(17), 3528-3549.

Muslim, A., Ismail, W. K. W., Rasid, S. Z. A., \& Selemani, R. D. A. (2014). The Impact of Human Resource Management Practices on Performance: Evidence from a Public University. The TQM Journal, 26(2), 125-142. https://doi.org/10.1108/TQM-10-2011-0062

Ng, E. S. W., Gossett, C. W., Chinyoka, S., \& Obasi, I. (2016). Public vs private sector employment. Personnel Review, 45(6), 1367-1385. https://doi.org/10.1108/PR-10-2014-0241

Quaisar, I. K., Khulida, K. Y., \& Tan, F. (2014). The Effect of Human Capital, Reward System and Career Commitment on Career Success: Mediating Role of Counterproductive Work Behaviour in Higher Education Sector of Pakistan. 7th National Human Resource Management Conference, 14-19.

Quaisar, I. K., Shukor, D. A. S., \& Soffian, D. S. S. I. (2015). The influence of career planning and HRM practices on career success of faculty members in public sector universities of Pakistan. Journal of Resources Developement and Management, 9, 68-75.

Quaisar, I. K., Shukor, D. A. S., \& Soffian, D. S. S. I. (2016a). Career Success and Organizational Justice as the Potential Predictors of Perceived University Performance: A Study from Public Sector Universities of Pakistan. European Journal of Business and Management, 8(16), 131139. 
Quaisar, I. K., Shukor, D. A. S., \& Soffian, D. S. S. I. (2016b). The mediatingeEffect of career success on HRM practices and university Performance: A study from public sector universities of Pakistan. Current Economics and Management Research, 2(1), 1-8.

Quddus, A., Nugroho, B. S., Hakim, L., Ritaudin, M. S., Nurhasanah, E., Suarsa, A., ... Sudargini, Y. (2020). Effect of ecological, servant dan digital leadership style influence university performance? evidence from indonesian universities. Systematic Reviews in Pharmacy, 11(10), 408-417. https://doi.org/10.31838/srp.2020.10.64

Rabovsky, T. M. (2012). Accountability in higher education: Exploring impacts on state budgets and institutional spending patterns. Journal of Public Administration Research and Theory, 22(4), 675-70o. https://doi.org/10.1093/jopart/muro69

Rothaermel, F. T., \& Thursby, M. (2005). Incubator firm failure or graduation?: The role of university linkages. Research Policy, 34(7), 1076-1090. https://doi.org/10.1016/j.respol.2005.05.012

Saher, N., Bibi, S., Farmanullah, S., \& Abbas, S. (2014). Career Success in Pakistan: Human Capital and Social Networking. Middle East Journal of Scientific Research, 19(2), 163-171. https://doi.org/10.5829/idosi.mejsr.2014.19.2.2203

Seibert, S. E., \& Kraimer, M. L. (2001). The Five-Factor Model of Personality and Career Success. Journal of Vocational Behavior, 58(1), 1-21. https://doi.org/10.1006/jvbe.2000.1757

Shen, Y., Demel, B., Unite, J., Briscoe, J. P., \& Hall, D. T. (2014). Career success across 11 countries: implications for international human resource management. International Journal of Human Resource Management, (January 2015), 37-41. https://doi.org/10.1080/09585192.2014.962562

Tabiu, A., \& Nura, A. A. (2013). Assessing the Effects of Human Resource Management (Hrm) Practices on Employee Job Performance: a Study of Usmanu Danfodiyo University Sokoto. Journal of Business Studies Quarterly, 5(2), 247-259. Retrieved from http://search.ebscohost.com/login. aspx?direct=true\&db=bth\&AN=93458519\&site=ehostlive\&scope $=$ site

Tan, F., \& Khulida, K. Y. (2011). The Influence of Career Planning Towards Insurance Agents ' Strategy for Career Satisfaction. Journal of Business and Policy Research2, 6(2), 80-92.

Yudianto, I., Mulyani, S., Fahmi, M., \& Winarningsih, S. (2021). The influence of good university governance and intellectual capital on university performance in Indonesia. Academic Journal of Interdisciplinary Studies, 10(1), 57-70. https://doi.org/10.36941/ajis-2021-00o6

Zafar, J., \& Farooq, M. (2017). The Relationship between Protean Career Orientation and Perceived Employability: A Study of Private Sector Academics of Pakistan. Journal of Management Sciences, 4(2), 130-141. https://doi.org/10.20547/jms.2014.1704201

Zhang, Q. Z., Jiang, S., Liu, R., \& Liu, H. C. (2020). An integrated decision-making model for analyzing key performance indicators in university performance management. Mathematics, 8(10), 1-16. https://doi.org/10.3390/math8101729. 